Discussion Paper No. 09-011

What Drives the Efficiency of Hard Coal Fuelled Electricity Generation? An Empirical Assessment

Tim Hoffmann and Sebastian Voigt

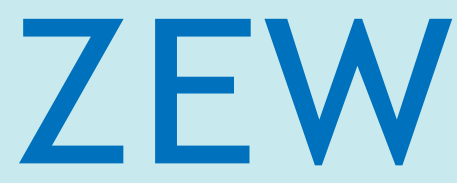

Zentrum für Europäische Wirtschaftsforschung $\mathrm{GmbH}$

Centre for European Economic Research 


\title{
Discussion Paper No. 09-011 \\ What Drives the Efficiency of Hard Coal Fuelled Electricity Generation? An Empirical Assessment
}

\author{
Tim Hoffmann and Sebastian Voigt
}

Download this ZEW Discussion Paper from our ftp server:

ftp://ftp.zew.de/pub/zew-docs/dp/dp09011.pdf

Die Discussion Papers dienen einer möglichst schnellen Verbreitung von neueren Forschungsarbeiten des ZEW. Die Beiträge liegen in alleiniger Verantwortung der Autoren und stellen nicht notwendigerweise die Meinung des ZEW dar.

Discussion Papers are intended to make results of ZEW research promptly available to other economists in order to encourage discussion and suggestions for revisions. The authors are solely responsible for the contents which do not necessarily represent the opinion of the ZEW. 


\section{Non-technical summary}

This paper assesses determinants of energy efficiency for the example of hard-coal fired power plants. Against the background of increasing greenhouse gas emissions and the significance of coal resources in both industrialized and emerging economies, more efficient ways to generate electricity are currently of high political relevance. Using econometric methods we test the role of factors such as hard coal abundance, the price of hard coal, the age of the power plants and inflows of foreign investments for the degree of efficiency. We apply panel data techniques to perform the analysis.

We find that higher prices for hard coal lead to higher energy efficiency in power plants, i.e. pricing pressure induces a more efficient way of electricity generation. Likewise, foreign direct investment has a positive impact on energy efficiency as it might support knowledge diffusion. The importance of coal abundance for energy efficiency depends on the measure that is chosen to represent this attribute. In general, our empirical results suggest that the more hard coal resources a country possesses, the less efficient is its electricity generation, i.e. power plant operators in countries with higher coal reserves might tend to be lavish with this resource. The estimates regarding the average age of the plants in a country imply that a high share of old facilities decreases the average degree of efficiency of the respective countries.

From an environmental policy perspective we conclude that flexible policy instruments such as taxes that internalise the external effects caused by greenhouse gas emissions as well as support for foreign investments are important means to foster energy efficiency. However, economic efficiency - even if contrasting with energy efficiency - must not be neglected in the design of energy policies. 


\section{Das Wichtigste in Kürze}

Dieses Papier untersucht Einflussfaktoren auf den Wirkungsgrad von Kraftwerken am Beispiel des fossilen Rohstoffs Steinkohle. Vor dem Hintergrund steigender Treibhausgasemissionen und aufgrund zahlreicher Steinkohlevorkommen sowohl in Industrieals auch in Entwicklungsländern ist es von großer Relevanz, die Effizienz solcher Kraftwerke zu erhöhen. Anhand ökonometrischer Methoden überprüfen wir, welche Auswirkungen Faktoren wie zum Beispiel die Menge an Rohstoffvorkommen, der Steinkohlepreis, das Kraftwerksalter und Zuflüsse ausländischer Investitionen auf den Wirkungsgrad haben. Dazu verwenden wir Paneldatenverfahren.

Die Ergebnisse unserer Analyse zeigen, dass höhere Steinkohlepreise zu einer höheren Energieeffizienz der entsprechenden Kraftwerke führen. Der Preisdruck kann zu einem verantwortungsvolleren Umgang mit dieser Ressource führen. Des Weiteren hat die Höhe ausländischer Direktinvestitionen einen positiven Einfluss auf unsere abhängige Variable, da solche Investitionen unterstützend auf Technologiediffusion einwirken können. Die Ergebnisse bezüglich der Menge an Steinkohlevorkommen hängen vom Indikator ab, der zur Messung dieser Eigenschaft verwendet wird. Sie legen allerdings nahe, dass höhere Vorkommen in einem Land zu niedrigeren Wirkungsgraden führen. Die Ursache dafür kann ein potentiell verschwenderischer Umgang mit Steinkohle seitens der Kraftwerksbetreiber sein, wenn große Steinkohlereserven verfügbar sind. Die Resultate im Hinblick auf das durchschnittliche Kraftwerksalter eines Landes implizieren, dass ein hoher Anteil alter Einrichtungen die Energieeffizienz verringert.

Von einem umweltpolitischen Gesichtspunkt kann gefolgert werden, dass flexible Politikinstrumente wie zum Beispiel Steuern, die durch Emissionen verursachte externe Effekte internalisieren und ausländische Investitionszuflüsse unterstützen, der Förderung eines höheren Wirkungsgrades dienlich sein können. Nichtsdestotrotz ist es wichtig, die ökonomische Effizienz nicht zu vernachlässigen, auch wenn sie im Widerspruch zu Energieeffizienzbestrebungen steht. 


\title{
What Drives the Efficiency of Hard Coal Fuelled Electricity Generation?
}

\section{An Empirical Assessment}

\author{
Tim Hoffmann ${ }^{\mathrm{a}}$ and Sebastian Voigt ${ }^{\mathrm{b}, *}$
}

Centre for European Economic Research (ZEW), P.O. Box 1034 43, D-68034 Mannheim, Germany

\author{
E-Mail address: hoffmann@zew.de, ${ }^{\text {b voigt@zew.de }}$ \\ *corresponding author
}

March 2009

\begin{abstract}
The efficiency of electricity generation in hard coal fired power plants varies considerably from country to country and over time. These differences occur both between developing and developed countries and between industrialised nations. The econometric analysis presented in this paper tests for the reasons of these discrepancies. In this examination abundance of hard coal and the price of hard coal are the two variables of our major interest. We assume that countries with an abundance of hard coal or relatively low costs of extraction show smaller degrees of efficiency than countries with poor deposits of this resource because the latter nations have a stronger dependency on efficient power plants than the former. Furthermore, higher prices should lead to more efficient electricity generation since production costs increase with growing hard coal prices. Our findings partially confirm these hypotheses and suggest that, among the chosen explanatory variables, hard coal abundance or the accessibility of hard coal, respectively, the hard coal price, the level of foreign direct investment inflows as well as the average power plant age are identified as principal drivers of power plant efficiency. From an environmental policy perspective we conclude that flexible policy instruments which internalise external effects caused by emissions as well as support for foreign investments are important means to foster energy efficiency. However, economic efficiency - even if contrasting with energy efficiency - must not be neglected in the design of energy policies.
\end{abstract}

Keywords: energy efficiency, natural resources, hard coal fired power plant

JEL classification: Q40, O13 


\section{Introduction}

At present, the greatest share of electricity generation is based on conventional fossil fuels. WEC (2007) states that this share amounts to 70\%, coal accounts for more than half of it. Against the background that global electricity demand will almost double until 2030, coal will remain an important resource for the production of electricity in the near future. It is unlikely that in the next years renewable sources are able to replace fossil energy carriers completely. In particular, looking at the high economic growth rates of developing countries like India, China or Brazil and, along with that, an increasing energy demand in these nations, it is unrealistic that coal based power generation will vanish soon. Therefore, the search for ways to improve energy efficiency essentially is unavoidable since greenhouse gas emissions have to be drastically reduced. There already exist technologies which show relatively high degrees of efficiency. For instance, supercritical and ultra-supercritical pulverised coal combustion achieves degrees of up to $43 \%$ or $45 \%$, respectively. For the process of integrated coal gasification combined cycle (IGCC) it is supposed that efficiency degrees of $56 \%$ can be accomplished until 2020, see Lako (2004).

We observe considerable differences in the efficiency of hard coal fired power plants between countries and over time. ${ }^{1}$ In the following econometric analysis we ask for the reasons of this circumstance. Primarily, we assume that the hard coal abundance situation of a country determines to a large extent the efficiency level of the country's hard coal power plants. In more detail, we expect a negative relationship between abundance and efficiency. This assumption is founded in the observation that countries with high deposits of natural resources often turn out to perform worse in economic growth rates. Auty (1993), for instance, terms this phenomenon "resource curse". In our analysis presented here, we do not give further contributions to that discussion. Our subject is related to the resource curse to that effect that abundance in general can be connected to worse performance rates, i.e. efficiency rates in our case. Furthermore, in nations which have large existing coal resources the costs of exploitation are usually lower than in countries that are less coal abundant. In this respect, there might be less incentive in coal abundant nations to generate electricity in the most efficient way. Instead it is conceivable that those countries tend to be lavish with their resources. The price of hard coal is one more potential source driving the efficiency level of

\footnotetext{
${ }^{1}$ In the remainder of this paper the term efficiency refers to energy efficiency or efficiency of electricity generation, respectively., if not otherwise indicated.
} 
electricity generation as higher resource prices should influence the efficiency of the generation process since production costs crucially depend on that indicator.

From an environmental economic point of view, efficiency of hard coal fired power plants is an essential subject since these facilities are responsible for a substantial part of carbon dioxide and other greenhouse gas emissions. The results of the examination thus should contain policy implications regarding a far-sighted operation of fossil fuels. In order to test for our assumptions, we perform an empirical analysis including several other explanatory variables. For this purpose, data on different indicators were gathered for 15 countries and approximately 25 years.

The remainder of the paper is structured as follows. The next section considers theoretical issues and gives a brief discussion of the respective literature. Section 3 outlines the approach of our empirical model and the data while Section 4 presents the results of the estimation. Section 5 concludes.

\section{Factors of Efficiency}

The tremendous variation in hard coal abundance across countries and differences in hard coal prices are presumed to be two of the principal causes for the occurring discrepancies in efficiency. Other potential influence factors include economic growth, the age of existing hard coal fired power plants, investments from foreign countries (especially in developing countries), and the membership in political communities or agreements on technological cooperation.

Sachs and Warner (2001) as well as Auty (1990) and Sachs and Warner (1995) analyse the impact of resource abundance on economic growth regarding the effects of the "resource curse" stating a decelerated growth in resource abundant countries. This "curse" is usually explained by a loss in competitiveness due to an appreciation of the exchange rate as a consequence of increasing resource revenues, see Auty (1993). Empirical examinations in Sachs and Warner (2001) confirm the existence of the curse, finding that no variable in their econometric model except for resource abundance easily explains the small growth rates of those countries.

There are several studies dealing with the analysis of power plant efficiency, see e.g. Golany et al. (1994) and Korhonen and Luptacik (2004). These analyses aim at measuring efficiency of single power plants using data envelopment analysis (DEA) and linear 
programming methods. Furthermore, these contributions examine the impact of efficiency on performance indicators, e.g. environmental and firm performance measures. Our approach differs in two respects. First, drawing on the example of hard coal, we investigate factors influencing efficiency by applying econometric methods. To our knowledge, so far there has been no attempt to analyse these causes in an empirical way. Second, we provide a countrywise consideration of the subject in contrast to the studies mentioned above which aim at using plant-specific approaches.

Our intention in the following analysis is similar to the contributions concerning the resource curse in the sense that resource abundance might lead to worse performance rates, in our case performance rates of efficiency degrees in the power plant sector. Figure 1 shows average efficiency levels of hard coal fired power plants in various countries. ${ }^{2}$ We see that differences do not only occur between developed and developing nations but also within the range of developed countries. For instance, efficiency degrees are similarly low for Turkey, the Czech Republic and Poland whereas Indonesia, India and South Africa have efficiency levels comparable to those of the developed countries listed here. In contrast, efficiency degrees in industrialised nations range from approximately 0.30 to 0.40 . This means that there must be explanations for the variations in efficiency other than the level of a country's development alone. As suggested earlier, our hypothesis is that the more hard coal resources a country owns the less efficient will be the electricity generation in hard coal fired power plants. Furthermore, not only the abundance of hard coal but also the cost of extraction should influence the performance of power plants, i.e. countries which can extract hard coal more cost efficiently are supposed to show lower efficiency rates. This assumption seems plausible since it is not eminently necessary for power plant operators in resource abundant countries to excessively increase their degree of efficiency. The same is true if we consider the case of cost efficient extraction of hard coal - operators reach economic efficiency through the costs rather than through the direct generation process. For the purpose of representing hard coal abundance, we will use two distinct measures. First, we adapt a suggestion of Sachs and Warner (2001) who express this variable as the ratio of natural resource exports to GDP. We slightly modify this measure and represent hard coal abundance by the ratio of coal exports to total primary energy supply (TPES). ${ }^{3}$ Second, we will also use the production level of hard coal as a gauge for abundance. This indicator also reflects the extraction cost argument

\footnotetext{
${ }^{2}$ Efficiency is defined as the ratio of electricity output from hard coal fired power plants as well as thermal output from combined heat and power (CHP) plants and their respective resource input, both measured in energy units.

${ }^{3}$ TPES of a natural resource results from production of the respective resource plus imports, stock changes, and reserves stored in bunkers etc. minus exports.
} 
outlined above. Lower extraction costs enable exploitation firms to extract more resources and thus to increase their profits. Production can decrease despite large coal deposits when extraction costs are too high. In particular, if extraction costs are greater than prices it may not be worthwhile to extract resources at all. Erdmann and Zweifel (2008), for instance, demonstrate that Germany's hard coal production declined over time in spite of increasing subsidies because German coal is not competitive compared to other countries. Therefore, production is a good indicator for hard coal accessibility rather than abundance alone. Further explanations for the choice of variables follow in Section 3.

Efficiencies

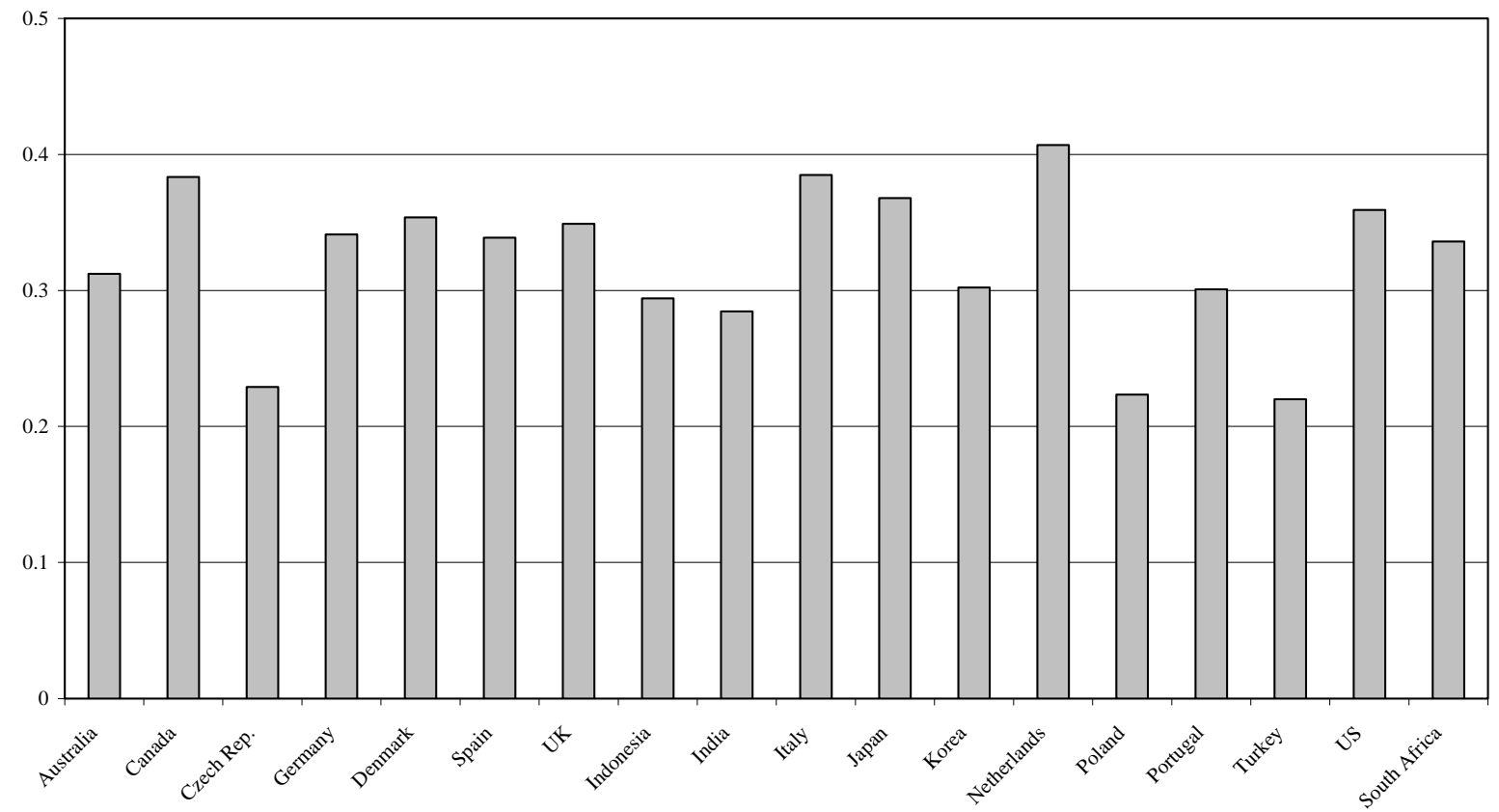

Figure 1: Average efficiency levels of hard coal fired power plants (source: IEA, 2007a; own calculations)

In addition to abundance, there are other potential factors influencing the variation in the efficiency of electricity generation. One of these factors certainly is the price of hard coal. We assume that higher resource prices lead to higher degrees of efficiency. GDP growth, as an indicator for the velocity of economic progress, is supposed to affect efficiency in the sense that faster growing economies adopt technological innovations and thus implement more sophisticated and more efficient plants. Moreover, the average age of the hard coal fired power plants in a country is assumed to influence efficiency. Younger power plant fleets supposedly use more innovative technologies which should result in higher average degrees of efficiency in the respective nations. Inflows of foreign direct investments (FDI) may lead to knowledge transfer and thus to knowledge spillovers. In the case of power plants this may 
initiate the introduction of more energy-efficient technologies. In particular, developing nations might benefit from this circumstance. Besides these factors, the membership of a country in international agreements on climate protection or in economic and political agreements potentially plays a significant role for energy efficiency. The limitation of emissions implicitly forces power plant operators to produce more efficiently in order to reduce the release of greenhouse gases. The membership in economic communities such as the European Union (EU) could lead to technological cooperation resulting in spillover effects which induce increasing energy efficiency. The EU has been a precursor in environmental subjects, e.g. the EU Greenhouse Gas Emissions Trading Scheme (EU ETS) and the European Community Law on the subject of environmental protection in the 1970s, presumably resulting in more effective ways of electricity generation. In 2005 the first phase of the EU ETS was launched. Although our database does not cover this period, it is possible that power plant operators in EU member states anticipate potential increases in the costs of electricity generation due to the existence of carbon emission prices caused by the ETS and thus invest in novel technologies which help produce electricity more efficiently. This issue distinguishes the EU from other developed countries in our analysis and can consequently serve as a reason for the impact of that variable. As the considered time horizon does not encompass the introduction of the EU ETS, its direct impacts will not yet be detectable.

\section{Modelling Approach and Data Sources}

In this section we are going to present the empirical model and its variables as well as the data sources used for the panel data analysis. The model includes measures on a yearly basis for all indicators introduced in the previous section. Our dependent variable, the efficiency $(E F F)$ of hard coal fired power plants, is computed by calculating the quotient of electricity output (plus thermal output in the case of combined heat and power (CHP) plants) and hard coal input, both in kilotonnes of oil equivalent per year (ktoe/a),

$$
E F F=\left(\text { electricity output }\left[\mathrm{GWh} \mathrm{el}_{\mathrm{el}} * 0.0861\right]+\text { thermal output }\left[\mathrm{TJ}_{\mathrm{th}} * 0.0239\right]\right) / \text { input }[\mathrm{ktoe}]
$$

As pointed out in the previous section, we use the ratio of exports of hard coal to TPES of hard coal as the first measure of the explanatory variable representing relative hard coal 
abundance of a country. ${ }^{4}$ The choice of this measure reflects an approach of Sachs and Warner (2001) as outlined above. Since we express hard coal exports as well as the respective TPES in energy units (ktoe/a), we decided to use this indicator instead of simply adopting Sachs's and Warner's approach which would require a monetary consideration of both measures. In order to justify our choice, we consider the fact that a country, which exports a lot of hard coal in relation to the TPES of this resource, is assumed to have large coal deposits. Furthermore, data availability on a time series basis is poor for hard coal reserves and hard coal resources making a panel data based consideration with these indicators difficult. The second gauge used to represent hard coal abundance is production of hard coal in each country, also measured in ktoe/a. We assume that countries with large hard coal reserves extract more resources than countries with small reserves. In contrast to the exportTPES ratio, production is an absolute measure. The export-TPES ratio primarily explains how much hard coal a country is able to deliver to the rest of the world in relation to the volume that remains in the country. Hence, this ratio is a proxy for the current endowment of the respective resources. As they describe similar issues, we do not use both indicators in the same estimations. In order to test the validity of our econometric model and its variables, it is appropriate to use distinct models for both measures.

Our second explanatory variable is the end-use price of hard coal in US dollars per tonne of oil equivalent (toe). Unfortunately, there are no prices available for large hard coal abundant countries like China or the Russian Federation resulting in the exclusion of these countries from our panel data set. We introduce first differences of the natural logarithms of (real) GDP in million US dollars of 1990 as a proxy for economic growth, presumably leading to higher efficiency levels in faster growing economies since they are supposed to adopt the most recent technologies which are able to generate electricity more efficiently. ${ }^{5}$ Furthermore, the average age of the hard coal based power plant fleet represents how up-to-date power plants of a specific nation are. The average is weighted by the capacities of the plants so that the variable represents the average age of one energy unit (in our case MW). We will estimate coefficients of linear and squared values of this variable in order to account for potential convex or concave interrelations. The database we used for computing the average age encompasses single blocks of power plants so that blocks added later to an older plant are counted as a new plant. In contrast, old blocks which are equipped with updated technology

\footnotetext{
${ }^{4}$ In order to specify the term "hard coal" we use a definition given in OECD/Eurostat (2004) assigning anthracite, coking coal and bituminous coal to hard coal. The data sources used for the computation of exports, production and TPES provide distinct information for these types of coal.

${ }^{5}$ The first difference of the natural logarithms of GDP corresponds approximately to the growth rate of GDP.
} 
are still counted at their original age, i.e. retrofitting is portrayed partly in the respective variables. A dummy variable indicates EU membership. It takes the value of one since the year of accession. As outlined in the previous section, EU membership can, for instance, be responsible for technological cooperation, which is facilitated in this community, as well as the anticipation of the EU ETS and stronger environmental regulations in general. In addition, we integrate inflows of FDI in current prices as a share in GDP to check whether inflows of foreign equipment, especially in developing countries, result in increased productivity caused by knowledge transfer. Since no energy-related FDI data was obtained, we use general FDI. We assume that both are correlated. Thus, general FDI may serve as a proxy for energyspecific FDI.

Table 1: Overview of data sources for variables

\begin{tabular}{ll}
\hline Variable & Data source \\
\hline Efficiency (EFF) & IEA (2007a) \\
Export-TPES ratio (EXP) & IEA (2007a) \\
Production (PROD) & IEA (2007a) \\
Price (PRICE) & IEA (2007b) \\
Gross Domestic Product (GDP) & UN (2007) \\
Average age (AGE) & WEPP (2007) \\
Inward FDI share $(F D I)$ & UNCTAD (2007) \\
\hline
\end{tabular}

Table 1 summarises the sources from which the respective data for the variables were retrieved. We see that the information concerning energy and resources was mainly obtained by the International Energy Agency (IEA), in particular the IEA Energy Balances which offer a large compendium of energy related data. Moreover, additional socio-economic data were obtained by several UN organizations. Data for the average age of the corresponding power plant fleets are obtained from the UDI World Electric Power Plants Database. The country choice includes several essential nations showing large hard coal deposits and being major trade partners of hard coal. ${ }^{6}$ As pointed out above, we had to exclude two important countries, China and Russia, because data on the respective hard coal prices are not available. The time scale of the data ranges from 1978 to 2003 for most developed countries although there are countries providing less information. Nonetheless, we also included those nations to our examination in order to broaden the data basis and thus the perspective for the analysis. In this

\footnotetext{
${ }^{6}$ Countries serving as cross-sectional units are: Australia, Canada, Czech Republic, Germany, India, Indonesia, Italy, Japan, Poland, Republic of Korea, Republic of South Africa, Spain, Turkey, the United Kingdom, and the United States.
} 
manner, we receive a unique unbalanced panel data set including variables which depict a multitude of properties that we consider important for our model.

We set up two panel data models to analyse the impact of the portrayed variables on power plant efficiency. The models differ in the consideration of the variable depicting hard coal abundance, i.e. the hard coal export-TPES ratio and hard coal production are not included simultaneously in the same model. The reason is that we expect both variables to have similar effects, i.e. they are presumably highly correlated. Since we assume that changes in most indicators need some time to actually affect efficiency, we represent each explanatory variable, except for the average age and the dummy, with a one year lag to attain a more realistic picture of the subject. We will apply the within group-estimator, see e.g. Hsiao (2003), and the Arellano-Bond estimator (Arellano and Bond, 1991). When using withingroup estimation, we consider each approach using individual and time fixed effects. The choice of random effects does not seem appropriate since we do not consider a small random sample of a large population but take into account nearly all available data points we are interested in. Hence, the first model looks as follows:

\section{Model (1)}

$\ln E F F_{i, t}=\alpha+\beta_{1} \ln E X P_{i, t-1}+\beta_{2} \ln P R I C E_{i, t-1}+\beta_{3} \ln \left(G D P_{i, t-1} / G D P_{i, t-2}\right)+\beta_{4} A G E_{i, t}$

$$
+\beta_{5} A G E_{i, t}^{2}+\beta_{6} F D I_{i, t-1}+\beta_{7} E U_{i, t}+e_{i, t}
$$

Accordingly, the second model is:

\section{Model (2)}

$\ln E F F_{i, t}=\alpha+\beta_{1} \ln P R O D_{i, t-1}+\beta_{2} \ln P R I C E_{i, t-1}+\beta_{3} \ln \left(G D P_{i, t-1} / G D P_{i, t-2}\right)+\beta_{4} A G E_{i, t}$

$$
+\beta_{5} A G E_{i, t}^{2}+\beta_{6} F D I_{i, t-1}+\beta_{7} E U_{i, t}+e_{i, t}
$$

Thus, Model (1) and (2) only differ with respect to the first explanatory variable. As outlined above, the error components $e_{i, t}$ contain country and time fixed effects when employing the within-group estimator. The Arellano-Bond GMM regression uses dynamic effects and thus the first and second lag of efficiency are introduced in addition to the other explanatory variables. We expect $\beta_{1}$, the coefficient belonging to the export-TPES ratio and production, respectively, to be negative, as explained above. The coefficient regarding the hard coal price, $\beta_{2}$, is assumed to be positive. We suppose that pricing pressure should lead to more efficient ways of electricity generation due to the more expensive access to hard coal 
resources. As stated earlier, we include the first difference of natural logarithms of GDP. Consequently, the corresponding coefficient, $\beta_{3}$, is assumed to be positive as well, since we suppose that higher economic growth is caused by technological development and thus results in higher efficiency degrees. We expect a negative relationship between the average age of the hard coal based power plant fleet and efficiency. Hence, at least the sign for the coefficient belonging to the squared age, $\beta_{5}$, should be negative. The inward FDI share is supposed to augment efficiency due to the following line of reasoning. Especially in poorer nations the inflows of foreign capital might lead to technological progress and thus to more effective generation methods. For this reason we expect the respective coefficient, $\beta_{6}$, to be positive. Unfortunately, we were not able to obtain FDI data regarding the electricity sector which would certainly extend the insights drawn from the empirical model. However, the inclusion of general FDI inflows can also serve our purpose as we are interested in the general impact of foreign assets on energy efficiency, too. Furthermore, general FDI inflows are assumed to be correlated with electricity-specific FDI inflows, so the former may serve as a proxy for the latter. Finally, membership in the EU is assumed to have a positive effect on the efficiency of hard coal power plants as outlined in the previous section. The estimation results are presented in Section 4.

Table 2: Descriptive statistics of data

\begin{tabular}{lcccc}
\hline Variable & Mean & Std. dev. & Min & Max \\
\hline Efficiency & 0.33 & 0.08 & 0.08 & 0.48 \\
Export-TPES ratio & 0.50 & 1.10 & 0.01 & 6.92 \\
Production & 51076.98 & 86595.25 & 50.36 & 409217.6 \\
Price & 68.90 & 41.44 & 4.43 & 233.96 \\
GDP (log difference) & 0.03 & 0.03 & -0.13 & 0.12 \\
Average age & 9.84 & 6.51 & 0 & 31.51 \\
Inward FDI share & 0.01 & 0.03 & -0.07 & 0.26 \\
\hline
\end{tabular}

Note: 254 observations.

Table 2 summarises descriptive statistics of all variables except for the dummies. Note that efficiency to some extent shows high values of up to 0.48 . This is due to the inclusion of CHP plants which reach much higher efficiency levels than pure electricity plants. Table 3 lists correlations between the depending and each explanatory variable. The relationship between efficiency and the export-TPES ratio and production, respectively, does not seem as strong as we suggested. However, strong connections between efficiency and the hard coal 
price, average age and EU membership in terms of relatively high correlations can be observed. We refer to the regression results in the following section to find out whether hard coal abundance and the hard coal price, the variables of our major interest, have a significant impact on power plant efficiency and to see which of the other measures significantly influence the dependent variable.

Table 3: Correlation analysis of the panel data set

\begin{tabular}{|c|c|c|c|c|c|c|c|c|c|}
\hline & Efficiency & $\begin{array}{c}\text { Export- } \\
\text { TPES } \\
\text { ratio }\end{array}$ & Production & Price & $\begin{array}{c}\text { GDP } \\
\text { (ln } \\
\text { diff.) }\end{array}$ & $\begin{array}{l}\text { Av. } \\
\text { age }\end{array}$ & $\begin{array}{l}\text { Av. } \\
\text { Age } \\
\text { (squ.) }\end{array}$ & $\begin{array}{c}\text { Inward } \\
\text { FDI }\end{array}$ & EU \\
\hline Efficiency & 1.00 & & & & & & & & \\
\hline $\begin{array}{l}\text { Export- } \\
\text { TPES ratio }\end{array}$ & -0.05 & 1.00 & & & & & & & \\
\hline Production & 0.05 & 0.40 & 1.00 & & & & & & \\
\hline Price & 0.38 & -0.37 & $-0-35$ & 1.00 & & & & & \\
\hline $\begin{array}{l}\text { GDP (log } \\
\text { difference) }\end{array}$ & 0.13 & -0.06 & 0.01 & 0.23 & 1.00 & & & & \\
\hline $\begin{array}{l}\text { Average } \\
\text { age }\end{array}$ & 0.23 & 0.15 & 0.20 & 0.29 & 0.08 & 1.00 & & & \\
\hline $\begin{array}{l}\text { Average } \\
\text { age } \\
\text { (squared) }\end{array}$ & 0.19 & 0.13 & 0.20 & 0.25 & 0.09 & 0.98 & 1.00 & & \\
\hline $\begin{array}{l}\text { Inward FDI } \\
\text { share }\end{array}$ & -0.13 & 0.231 & -0.09 & -0.03 & 0.16 & 0.46 & 0.46 & 1.00 & \\
\hline EU & 0.28 & -0.06 & -0.11 & 0.60 & 0.09 & 0.37 & 0.32 & 0.01 & 1.00 \\
\hline
\end{tabular}

\section{Estimation Results}

In order to perform a regression analysis of the models outlined in the previous section we employ within-group estimation and GMM estimation, the latter using the Arellano-Bond estimator, as describe above. Table 4 summarises the estimation results for Models (1) and (2). Each of the four estimations is significant as a whole according to the probability values of the F-tests (within-group estimator) and Wald-tests (Arellano-Bond estimator). Basically, the results reflect our expectations. However, the outcomes representing hard coal abundance 
of a country, one of the explanatory variables of our major interest, are ambiguous. The coefficient of the export-TPES ratio used in Model (1) is not significant in both estimations. In contrast, the coefficient belonging to the production level used in Model (2) is significant and negative in either corresponding estimation. In general, this result confirms our hypothesis that the more hard coal resources a country possesses the less efficient is electricity generation in this country's power plants. Similarly, the coefficient of the hard coal price, the other variable of our main interest, is significant and positive in three of the four estimations. This outcome in principle supports our initial assumption as well. Based on our empirical considerations, pricing pressure leads to higher efficiency levels.

Table 4: Regression results

\begin{tabular}{lcccc}
\hline $\begin{array}{l}\text { Dep. var. } \\
\text { Efficiency }\end{array}$ & $\begin{array}{c}\text { Model (1) } \\
\text { Within }\end{array}$ & $\begin{array}{c}\text { Model (1) } \\
\text { Arellano-Bond }\end{array}$ & $\begin{array}{c}\text { Model (2) } \\
\text { Within }\end{array}$ & $\begin{array}{c}\text { Model (2) } \\
\text { Arellano-Bond }\end{array}$ \\
\hline Export-TPES & $0.01(0.01)$ & $-0.01(0.01)$ & -- & -- \\
ratio & -- & -- & $-0.06^{* * *}(0.01)$ & $-0.02^{* * *}(0.01)$ \\
Production & $0.05^{* * *}(0.02)$ & $0.04^{* * *}(0.01)$ & $0.04^{* *}(0.02)$ & $0.02(0.01)$ \\
Price & $-0.04(0.17)$ & $0.04(0.12)$ & $-0.17(0.19)$ & $-0.06(0.10)$ \\
GDP (log & & & & \\
difference) & $0.01^{* *}(0.01)$ & $0.01^{*}(0.00)$ & $0.07^{* * *}(0.01)$ & $0.02^{* * *}(0.01)$ \\
Average age & $-0.00(0.00)$ & $-0.00(0.00)$ & $-0.00^{* * *}(0.00)$ & $-0.00^{* * *}(0.00)$ \\
Average age & & & & \\
(squared) & $1.27^{* * *}(0.26)$ & $0.57^{* * *}(0.18)$ & $1.26^{* * *}(0.32)$ & $0.41^{* *}(0.18)$ \\
Inward FDI share & $0.07(0.07)$ & $-0.01(0.02)$ & $0.05(0.09)$ & $-0.05^{*}(0.03)$ \\
EU & -- & $0.35^{* * *}(0.10)$ & -- & $0.56^{* * *}(0.13)$ \\
Efficiency (lag 1) & -- & $0.21^{* * *}(0.03)$ & --- & $0.20^{* * *}(0.07)$ \\
Efficiency (lag 2) & $-1.41^{* * *}(0.08)$ & $-0.00(0.00)$ & $-1.15^{* * *}(0.15)$ & $-0.00^{* *}(0.00)$ \\
Constant term & 254 & 232 & 265 & 246 \\
No. of obs. & 0.43 & -- & 0.53 & -- \\
$R^{2}$ & 0.00 & 0.00 & 0.00 & 0.00 \\
F-test/ Wald-test & & & & \\
(p-value) & & & & \\
\hline
\end{tabular}

Note: Standard errors are displayed in parentheses. Variables indicated with *, ** and *** show significance at $10 \%, 5 \%$ and $1 \%$ levels, respectively.

The impact of GDP growth on the dependent variable is not significant in any estimation. Hence, our initial assumption that large increases of national income lead to rising 
efficiency degrees is not confirmed by the estimation results. The supposed effects of technological progress are potentially included in the time effects. In addition, we also estimated a model (not reported in this paper) that includes GDP per capita instead of GDP growth with the same results. The impact of GDP per capita is not significant in these models either. This supports the reported empirical findings. Neither economic growth nor the wealth level significantly influences efficiency of hard coal fired power plants.

The impact of the average plant age is somewhat surprising. The coefficient of the linear term is significant and positive in each estimation whereas the coefficient of the squared age is negative in every result but significant only in Model (2). These results imply a positive relationship between average age and efficiency as long as the power plant fleet is still young. However, the marginal effect is decreasing, i.e. the larger the average age the weaker is the positive relationship to efficiency. This is due to the negative sign of the coefficient of the squared average age. Moreover, the negative coefficient also indicates that after a certain time span the relationship becomes negative, at least in the cases where the squared variable is significant. There are two possible explanations for this circumstance. First, new power plants need some operation time to reach full efficiency. The efficiency gains are quite large in the first years but decrease with growing age until, after a certain period, efficiency declines the older the power plant fleet gets. The second explanation pertains to the different development levels of the considered countries. Usually, the average age is higher in developed countries than in developing countries. In our database countries like India, Indonesia or the Republic of Korea started building hard coal fired power plants on a large scale much later than European or North American nations. However, since technological standards are presumably higher in the latter nations due to higher experience, electricity generation is more efficient there, too. In developing countries the average age is rarely higher than 15 years whereas in the industrialised world it is often greater than 25 years. This fact might explain the positive relationship for low age values.

The coefficient belonging to FDI inflows as a share in GDP is positive and significant in all regressions. This positive relationship was expected as outlined above. Although we used general FDI instead of energy-related FDI data, a strong connection to efficiency of electricity generation cannot be denied. Since we also introduced the FDI variable as a proxy for knowledge transfer, these results indicate that inflows of foreign investments can be responsible for the diffusion of novel technologies and thus foster technological development, particularly in smaller countries as their inward FDI share is usually higher than in large nations. 
EU membership does not have a significant impact on power plant efficiency in most regressions. Only in the GMM estimation of Model (2) the variable is significant at the $10 \%$ level and negative in contrast to our hypothesis stated above. The general outcomes of nonsignificance imply that other variables have a stronger influence on power plant efficiency than EU membership. Our line of reasoning above was that, besides higher technological cooperation in the EU, the anticipation of the first phase of the EU ETS and an expected increase of production costs as a consequence thereof would lead to higher degrees of efficiency. However, direct impacts of the EU ETS cannot yet be measured in our analysis as the time period covered by our database only reaches until 2003.

Regarding the differences between all regressions, we can state that the two indicators for hard coal abundance, the export-TPES ratio and the production level show different behaviour. While the impact of the former is not significant, the negative influence of the production level indicates that larger deposits of hard coal and easier, cheaper extraction possibilities lead to a more lavish dealing with the resource in terms of lower degrees of efficiency of electricity generation. Nevertheless, the question concerning the better indicator for hard coal abundance remains. With regard to the $R^{2}$ values of the within-group estimations we can at least say that the regression including the production level explains a higher variance share implying that this is probably the better variable choice. This indicates that we observe a negative relationship between hard coal abundance and energy efficiency. Moreover, the findings concerning the hard coal price also confirm our assumption that higher prices lead to more productive ways of electricity generation. Consequently, the variables of our major interest, i.e. hard coal abundance and hard coal price, demonstrate the expected behaviour as stated in Section 2. Furthermore, FDI inflows show a significant positive impact on efficiency. Hence, an investigation of the results in Table 4 exposes the production level, the hard coal price and the share of FDI inflows in GDP as the driving elements for the degree of efficiency among our chosen indicators. We also observe a significant impact of the average age of the power plant fleet. However, as pointed out above these results should be handled with care.

\section{Conclusions}

This study analysed empirically potential drivers of the degree of efficiency in hard coal fired power plants. We found that the impact of hard coal abundance on the efficiency of 
power generation, one of the two variables of our major interest, is ambiguous depending on what measure is chosen for the representation of that indicator. The influence of the exportTPES ratio of hard coal is not significant whereas hard coal production shows significant negative behaviour. As production also contains a gauge for extraction costs, in the sense that higher costs imply lower production levels, we can state that higher accessibility of hard coal may result in lower efficiency levels of hard coal fired power plants. In addition, most of the regressions confirmed that increasing hard coal prices, the other variable we are primarily interested in, result in growing degrees of efficiency. Our findings further imply that inflows of foreign investments have a positive impact on the dependent variable and thus knowledge transfer also plays an important role for efficiency. Hence, the hard coal price and the FDI share as well as the production level turn out to be the key elements driving productivity of hard coal based electricity generation considering the variables included in our investigation. Moreover, the influence of average power plant age is not completely revealed by our analysis. We found a positive relationship between age and efficiency with declining additional gains per year of age as long as the power plant fleet is young. However, for older fleets the relationship is negative suggesting that very old plants should be shut down. This might be due to the fact that developing countries usually have younger power plants in contrast to industrialised nations and that power generation in the latter is per se more efficient.

From an environmental political viewpoint an increase of efficiency of electricity generation based on fossil fuels is important as it leads to a reduction in carbon dioxide emissions per produced energy unit. Therefore, public authorities should find appropriate policy instruments in order to increase power plant efficiency. Especially in hard coal abundant countries this could possibly imply that, for instance, a reduction of existing hard coal subsidies could contribute to make the electricity generation process more efficient and cleaner. Moreover, with regard to our findings concerning the hard coal price, flexible policy mechanisms which increase end-use prices of resources might be advisable, e.g. taxes for resource use. The introduction of the EU ETS could help reach these aims due to higher costs of electricity generation caused by the existence of a market for carbon dioxide emission allowances. Future research on that subject should examine the impact of the carbon price and other variables related to the EU ETS on the efficiency of electricity generation. Unfortunately, so far not enough data are available as the first phase was launched in 2005. Our data set, however, ranges only from 1978 to 2003. Finally, regarding the results of FDI 
inflows, governments should establish investment incentives for foreign firms and in this way create possibilities for transferring more efficient electricity generation technologies.

Nevertheless, an investigation in an analytical economic model is desirable in order to analyse whether adverse effects result from the recommended instruments. Those effects could in the worst case contain the substitution of hard coal by other fossil fuels which would not be useful to achieve the aim of emissions reductions. On the other hand, substitution towards renewable energy carriers is another possible outcome of these tools implying the attainment of decreasing carbon dioxide emissions. Furthermore, policy instruments should be handled with care since energy efficiency does not necessarily have to accompany economic efficiency. There is no market failure present if hard coal prices reflect scarcity correctly. This might be an argument for the use of flexible instruments such as taxes in order to reach the respective scarcity price that also internalises external effects caused by emissions. Mennel and Sturm (2008) show that flexible mechanisms and informational actions should be preferred over standards since the latter are rarely cost efficient. Hence, standards are able to increase energy efficiency while reducing economic efficiency. In addition, even environmentally benefitting policy actions might decrease energy efficiency, e.g. carbon capture and sequestration (CCS) and the reduction of sulphur dioxide emissions.

Future empirical research should attempt to include R\&D investments related to hard coal based power generation or to energy in general. This will, in particular, depend on data availability. The IEA provides a database on energy-related R\&D, see IEA (2007c). Unfortunately, it is insufficient for many countries considered in this analysis, especially for the non-OECD states. The inclusion of the available data would constrict the number of observations and rule out important developing countries from our analysis. Furthermore, an analytical approach regarding efficiency, e.g. an equilibrium model covering the energy sector, might be supportive for the assessment of possible policy instruments.

\section{Acknowledgements}

The authors are grateful to Wilko Smidt for support in data collection. Furthermore, we thank Ulrich Oberndorfer, Niels Anger, Andreas Ziegler, Eva Benz, Bodo Sturm and Andreas Löschel for valuable scientific comments and suggestions. Funding by the Volkswagen Foundation within the project "The Significance of Germany as a Site for Power Plant 
Construction against the Background of an Increasing Internationalization of Innovation Processes” is gratefully acknowledged.

\section{References}

Arellano, M., Bond, S. (1991), Some Tests of Specification for Panel Data: Monte Carlo Evidence and an Application to Employment Equations. Review of Economic Studies, 58, 277-297.

Auty, R.M. (1990), Resource-Based Industrialization: Sowing the Oil in Eight Developing Countries. Oxford University Press, New York.

Auty, R.M. (1993), Sustaining Development in Mineral Economies - The resource curse thesis. Routledge, London.

Erdmann, G., Zweifel, P. (2008), Energieökonomik - Theorie und Anwendungen. Springer-Verlag, Berlin, Heidelberg.

Golany, B., Roll, Y., Rybak, D. (1994), Measuring efficiency of power plants in Israel by data envelopment analysis. IEEE Transactions on Engineering Management 41, 291-301.

Hsiao, C. (2003), Analysis of Panel Data. Second Edition, Cambridge University Press, New York.

IEA (2007a), International Energy Agency World Energy Statistics and Balances. Available at: http://titania.sourceoecd.org/vl=8744049/cl=33/nw=1/rpsv/statistic/s35 about.htm?jnlissn=16834 $\underline{240}$

IEA (2007b), International Energy Agency Energy Prices and Taxes. Available at: http://masetto.sourceoecd.org/vl=502329/cl=19/nw=1/rpsv/ij/oecdstats/1683626x/v345n1/s8/p1

IEA (2007c), International Energy Agency Energy Technology $R \& D$. Available at: http://caliban.sourceoecd.org/vl=9912032/cl=18/nw=1/rpsv/statistic/s30_about.htm?jnlissn=17266 $\underline{564}$

Korhonen, P.J., Luptacik, M. (2004), Eco-efficiency analysis of power plants: An extension of data envelopment analysis. European Journal of Operational Research 154, 437-446.

Lako, P. (2004), Coal-fired Power Technologies - Coal-fired Power Options on the Brink of Climate Policies. Energy Research Centre of the Netherlands (ECN) report, ECN-C-04/076. Available at: http://www.ecn.nl/docs/library/report/2004/c04076.pdf

Mennel, T., Sturm, B. (2008), Energieeffizienz - eine neue Aufgabe für staatliche Regulierung? ZEW Discussion Paper 08-004, Mannheim. Available at: ftp://ftp.zew.de/pub/zew-docs/dp/dp08004.pdf

OECD/Eurostat (2004), Energy Statistics Manual. Organisation for Economic Co-operation and Development, International Energy Agency, Eurostat.

Sachs, J.D., Warner, A.M. (1995), revised 1997, 1999. Natural resource abundance and economic growth. National Bureau of Economic Research, Working Paper No. 5398, Cambridge, MA. 
Sachs, J.D., Warner, A.M. (2001), The curse of natural resources. European Economic Review 45, 827-838.

UN (2007), United Nations Statistics Division - National Accounts. Available at: http://unstats.un.org/unsd/snaama/selectionbasicFast.asp

UNCTAD (2007), Foreign Direct Investment Database of United Nations Conference on Trade and Development. Available at: http://stats.unctad.org/fdi/ReportFolders/ReportFolders.aspx

WEC (2007), World Energy Council - Survey of Energy Resources. World Energy Council, London. WEPP (2007), Platts UDI World Electric Power Plants Database. The McGraw-Hill Companies. 